\begin{tabular}{c}
\hline Review of \\
ECONOMICS \\
and \\
INSTITUTIONS
\end{tabular}

Review of Economics and Institutions ISSN 2038-1379 DOI 10.5202/rei.v4i2.124

Vol. 4 - No. 2, Spring 2013 - Article 2

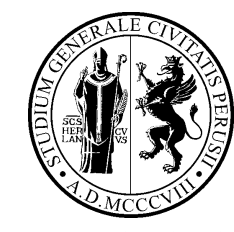

www.rei.unipg.it

\title{
Labour Relations Quality and Productivity: an Empirical Analysis on French Firms
}

\author{
Gilbert Cette \\ Banque de France, \\ Université d'Aix- \\ Marseille (AMSE)
}

\author{
Nicolas Dromel \\ Paris Paris School of \\ Economics, CNRS, \\ Centre d'Economie \\ de la Sorbonne
}

\author{
Rémy Lecat Anne-Charlotte Paret \\ Banque de Banque de France, ENSAE \\ France
}

\begin{abstract}
We empirically characterise how good labour relations can alleviate the negative impact on productivity of regulatory constraints or workforce opposition. The estimates are based on a unique survey of French manufacturing firms collected by the Banque de France over the period 1991-2008. Our main results may be summarised as follows: i) 'workforce or union opposition' interacted with 'regulatory constraints' has a negative significant impact on total factor productivity (TFP). When this interaction is not taken into account, a deteriorated labour climate, through workforce or union opposition, weighs directly on TFP. But when this interaction is taken into account, this negative impact relies solely on the combination of regulatory constraints and labour opposition: workers or unions can successfully oppose management's decisions and weigh on TFP when they can use or threaten to use appropriate regulation; otherwise, their opposition may be harmless; ii) 'regulatory constraints' interacted with 'branch or firm agreement' has a positive significant impact on TFP. These agreements, which can only be obtained if labour relations are supportive, would be used by firms to offset the negative impact of regulatory constraints. This favourable impact can be obtained through two channels: first, informally, a good labour climate can lead to a flexible implementation of regulation; second, formally, the French labour code incorporates provisions that allow firm or branch agreements to adapt or even alleviate the constraints of regulation.

These results emphasise that the implementation of regulatory constraints and their impact on productivity crucially hinges on the quality of labour climate.
\end{abstract}

JEL classification: J53; J52; J51

Keywords: labour relations, collective bargaining, trade unions, productivity

The authors would like to thank, without implicating, Philippe Askenazy, Pierre Cahuc, Romain Duval, Denis Fougère, Eva Moreno-Galbis, Thomas Piketty, seminar participants at the Banque de France, at the Paris School of Economics and anonymous referees, as well as participants to the T2M 2012, AFSE 2012, CEA 2013 and JMA 2013 conferences for helpful comments. Antoine Bonleu and Claire Martin are acknowledged for their help in data collection. The views expressed herein are those of the authors and do not necessarily reflect the views of the institutions they belong to.

$\square$ Corresponding author. Address: Banque de France, DEMS, 46-2400, 31 rue Croix des Petits Champs, 75001 Paris, France. (E-mail: gilbert.cette@banque-france.fr).

\section{Recommended Citation}

Cette, G., Dromel, N., Lecat, R., Paret, A.-C. (2013). Labour Relations Quality and Productivity: an Empirical Analysis on French Firms. Review of Economics and Institutions, 4(2), Article 2. doi: 10.5202/rei.v4i2.124. Retrieved from http://www.rei.unipg.it/rei/article/view/124

Copyright (C) 2013 University of Perugia Electronic Press. All rights reserved 


\section{Introduction}

The present paper aims at analysing in an original way the impact on productivity of good labour relations. We use an original database containing 7,441 observations, corresponding to 1,545 French companies, over 1991-2008. To our knowledge, this company-level database is unique in allowing such an analysis.

A large amount of literature has been analysing the impact of labour relations quality on firm performances, but does not really convey a unified and simple message ${ }^{1}$. The labour relation quality is usually appraised through unionization and works council statistics, or through worker wellbeing indicators (strikes, grievance fillings...) coming from surveys. Firm performances are often characterized by variables such as labour productivity, total factor productivity or profitability.

The impact of unionization on the average wage is found to be usually but not always positive, while the impact on firm profitability is ambiguous, either positive or negative depending on the study. The surveys from Hirsch (2007) and Morikawa (2010) show that while some analyses find a positive impact of unionization on productivity, some other papers do find a non-significant impact or even a negative one. For example, both on US individual firm data, Brown and Medoff (1978) find a positive impact while Clark (1984) obtains a negative one. On the same type of data, Cooke (1994) or Black and Lynch (2001) suggest an explanation for this contrast: unionization would have a positive impact on productivity only in firms where the employer promotes joint decisions and incentive-based compensations and a negative impact in firms that maintain a more traditional labour management. Moreton (1999) shows on British establishment-level data that higher union bargaining power does not necessarily lower labour productivity in union firms, ceteris paribus.

The survey from Addison (2005) highlights contrasted conclusions regarding the impact of works councils on productivity. Addison et al. (2000) on German and British firms and Addison et al. (2001) on German firms observe a positive impact in large firms only. Fairris and Askenazy (2010) find, on French firms, no evidence of a positive impact of works councils on firm productivity and even some limited evidence of a negative effect. Hübler and Jirjahn (2003) provide an empirical explanation of these different results. Based on German firms, their study shows a positive impact of works councils on productivity only within firms covered by collective agreements, which is in line with the theoretical insights of Freeman and

\footnotetext{
${ }^{1}$ We report here only empirical approaches. Some papers propose theoretical approaches, and for example, Cardona and Sánchez-Losada (2005) show, through a theoretical modelisation, that an increase in unions' bargaining power may have a positive impact on the final goods production (productivity) in a right-to-manage bargaining setup, while a negative one in an efficient bargaining framework.
} 
Lazear (1995) ${ }^{2}$. Works councils can improve firm productivity only in situations where the quality of labour relations is good enough to prevent some inefficiency risks. The positive impact on productivity results from the interaction between works councils and these good labour relations, works councils being however a negative productivity factor if taken individually. In a recent paper, Jirjahn and Mueller (2012) show on German establishment data that works councils are associated with higher productivity in domestic-owned establishments, but with a lower one in foreign-owned establishments. Foreign ownership would involve strong tensions with institutional patterns of the host country.

A big part of the literature has focused on indicators such as strikes (Kleiner et al. 2002; Mas, 2008), grievance fillings (Ichniowski, 1986; Katz et al. 1983), absenteeism (Katz et al. 1983), tough union leaders (Lazear, 1995; Kleiner et al. 2002) and labour climate surveys among managers or workers of a specific plant (Katz et al. 1983; Deery and Iverson, 2005; Katz et al. 1987). These papers support the negative impact of a deteriorated labour climate on productivity or product quality. More precisely, Deery and Iverson (2005) point out the building blocks of a good labour climate, as reflected by an employee survey: in particular, the union's willingness to adopt an integrative approach to bargaining and the management's willingness to share information freely with the union. However, these papers are based on case studies (different plants of the same firm in automobile, aircraft, paper mills industry...) and do not address the impact of firm or branch agreements, or of the interactions between these agreements and labour relations. We precisely aim at filling this gap.

Our empirical analysis is based on a unique survey of French firms, about the obstacles they may face in increasing their production factor utilisation: the survey on factor utilisation degrees (FUD hereafter). Characterising labour climate through an indirect and focused question is an efficient way of getting unbiased answers from managers. Indeed, when asked directly about labour climate in another French labour climate survey, REPONSE, 90\% of managers assessed it to be "calm" or "rather calm", while more precise questions about labour conflicts or questions to workers and their representatives revealed on the contrary a deteriorated labour climate. We merge these data with FiBEn, another individual company dataset collected by the Banque de France. FiBEn is a very large database including balance sheets and profit and loss accounts from annual tax statements, which can be used to compute total factor productivity (TFP) and changes in output. The FUD survey has been carried out every year since 1989 by the Banque de France at the plant level. It not only provides rich insights about

2 "There are potential net social gains from works councils. But to work best and gain these potential benefits, the rules governing councils must be carefully written to bound the power of labor and management and 'fit' the broader labor system in which councils must function" (Freeman and Lazear, 1995, section 2.5). 
firm-level factor utilisation, but also a unique appraisal of rigidities faced by firms in increasing their capital workweek. Firms are directly asked to declare the presence of such rigidities, and to characterize their legal, social or technical nature. More precisely, entrepreneurs answered the following question: "If you had to increase your capital operating time, and if your sales potential could justify it, would you meet obstacles or brakes such as...?". The considered obstacles are: worker opposition, union opposition, absence of qualified workforce, bottleneck on commodities or supply, technical obstacles, legal or regulatory constraint, branch agreement, firm agreement, and other. The merge of these two databases results in an unbalanced sample of 7,441 observations, corresponding to 1,545 companies, over the period 1991-2008. To our knowledge, this individual company database is unique for allowing an empirical analysis concerning the impact of these rigidities on TFP. As in Hübler and Jirjahn (2003), our evidence of good labour relations lies in the existence of binding collective agreements, at the firm or at the branch level.

In France, large margins of improvement in labour relations quality may exist, as compared to other countries. Trade union density is the lowest among OECD countries (7.6\% in 2008 compared to $19.1 \%$ in Germany according to the OECD) and labour regulations at the national level rarely stem from union-employers negotiation. Aghion et al. (2011) highlight that in a cross-section of countries, state regulation of labour markets is negatively correlated with the quality of labour relations. They argue that state regulation crowds out the possibility for workers to experiment negotiation and learn about the potential cooperative nature of labour relations. This mechanism seems to be particularly relevant for France, where state intervention in the labour market regulation is widespread and significant. In France, the ability to conclude a collective agreement is a clear sign of good labour relations between employers and at least some unions. Hence, even if it is declared in the FUD survey as an obstacle to increase the capital operating time, the existence of a collective agreement (at the branch or the firm level) remains an appropriate proxy for good labour relations.

Our empirical strategy consists in estimating a relation where firm-level TFP is explained by output changes, wages per employee, year, sector-year and firm-specific fixed effects along with different obstacles declared by firms, these obstacles being considered individually or interacted for some of them. These estimates may face a double causality bias: firms benefitting from high TFP may be able to provide higher wages. Employers could therefore overcome worker or union opposition, better secure supply, attract talents and negotiate more favourable firm agreements by being able to provide more generous compensations for increased flexibility. In order to address this bias, we implemented an instrumentation strategy based on Hansen (1982) using lagged obstacles levels and changes as instruments. We did also control for wages. 
Our main results may be summarised as follows: i) 'workforce or union opposition' interacted with 'regulatory constraints' has a negative significant impact on total factor productivity (TFP). Regulatory constraints would become really binding when workers or unions use them as a tool to oppose management's decisions; ii) 'regulatory constraints' interacted with 'branch or firm agreement' has a positive significant impact on TFP. These agreements, which can only be obtained if labour relations are supportive, would be used by firms to offset the negative impact of regulatory constraints.

These results support the importance of labour relations quality, at the branch or the firm levels, as a powerful factor of productive performance. They provide an original confirmation to early insights in the literature (e.g. Freeman and Lazear, 1995).

Section 2 presents the data. Section 3 details the empirical strategy and section 4 comments on the results. Section 5 displays the outcome of several robustness checks and section 6 concludes.

\section{Data and Obstacles to Increase Capital Operat- ing Time}

\subsection{An Original Dataset}

Our empirical analysis merges two firm-level annual datasets constructed by the Banque de France: FiBEn and a survey on factor utilisation degrees (FUD).

FiBEn is a large database built on fiscal documents, including balance sheets and profit-and-loss statements. It features all French firms with sales exceeding $€ 750,000$ per year, or with a credit outstanding higher than $€$ 380,000 . Every year, these accounting data are available for about 200,000 firms. In 2004, FiBEn was covering $80 \%$ of the firms with 20 to 500 employees, and $98 \%$ of those employing more than 500 employees. This database allows calculating firm-level value added $(Q)$, the capital stock $(K)$, the volume of employment $(L)$ and computing total factor productivity (TFP):

- The value added volume $(Q)$ is calculated by dividing value added in current prices (production in value minus intermediate consumptions) by a national accounting index of value added price at the industry level (two digit decomposition level).

- The volume of capital $(K)$ sums gross capital volumes for buildings and equipment. Gross capital at historical price (as reported in tax statements) is divided by a national index for investment price, lagged with the mean age of gross capital (itself calculated from the share of depreciated capital in gross capital, at historical price). This measure corresponds to the volume of capital, usually by the end of a fiscal 
year. For this reason, we introduce a one-year lag for capital to compute share-weighted factor growth.

- The average employment level $(L)$ is directly available in FiBEn.

- Total factor productivity for firm $i$ in sector $j$ at date $t\left(T F P_{i j t}\right)$ is obtained by dividing total value added $Q_{i j t}$ by the volume of production inputs $V_{i j t}$, where:

$$
V_{i j t}=K_{i j t-1}^{1-\alpha_{j}} L_{i j t}{ }^{\alpha_{j}}
$$

with $\alpha_{j}$ the labour share in revenue for sector $j$, calculated from the median over firms in this industry, on the dataset period.

The FUD survey has been carried out each September since 1989 3 , 1,500 to 2,500 plants ${ }^{4}$ are covered by this survey, depending on the year. This dataset directly provides for each plant the annual growth rate of capital workweek (WK) and the level of labour workweek (WL).

While the FUD survey is carried out at the plant level, FiBEn gives information at the firm level. A difficulty in the data merge lies in the fact that some firms are multi plants. When several plants of a single firm were covered by the FUD survey, we aggregated for each year all plants of this firm, weighting them by their share in the firm's total employment. We considered the FUD survey answers to be representative enough when the employment level corresponding to this aggregation was higher than $50 \%$ of the one reported in FiBEn (otherwise, the firm was dropped from the final datase ${ }^{5}$ ). Each time one observation was missing for a given firm, we interpolated its value taking the average of its one-period past and one-period next observations.

The sample used in this paper is an unbalanced firm panel of 7,441 observations, corresponding to 1,545 companies, over the period 1991-2008. The criteria underlying this sample selection are detailed below.

\subsection{Obstacles to Shifts in Capital Operating Time}

Our dataset not only provides rich insights about firm-level factor utilisation, but also a unique appraisal of rigidities faced by firms in increasing their capital workweek. Firms were directly asked to declare the presence of such rigidities and to characterize their legal, social or technical nature. More precisely, entrepreneurs answered the following question: "If you had to increase your capital operating time, and if your sales potential could justify it, would you meet obstacles or brakes such as...?":

${ }^{3} 2002$ is unfortunately not present in the dataset since accidentally, paper questionnaires for the 2002 survey are no longer available at the Banque de France.

4 These plants are the ones usually covered by the Banque de France monthly survey on business climate.

${ }^{5}$ In the final dataset, only 55 observations correspond to multi-plants firms. 


\section{Worker opposition (WOPP)}

2. Union opposition (UOPP)

3. Absence of qualified workforce $(A B S)$

4. Bottleneck on commodities or supply (BOTT)

5. Technical obstacles (TOBS)

6. Legal or regulatory constraint (REG)

7. Branch agreement $(B R A)$

8. Firm agreement $(F I R)$

\section{Other}

Beyond reporting obstacles, firms were also asked to rank them. Given the potential heterogeneity in the firms' understanding of this ranking exercise, we preferred to particularly focus on the presence of an obstacle and made some methodological choices: in particular, some firms ranked systematically all obstacles, while some others selected just one, two or three obstacles. On the one hand, considering that an obstacle is present as soon as it is reported may be misleading, as some firms ranked all obstacles. On the other hand, considering only obstacles ranked in first position may rule out any possibility to analyse firms facing several rigidities. To deal with this "question understanding" potential bias, we choose to consider an obstacle as present if it is declared and ranked either in first, second or third position.

A strong correlation and possible confusion between different obstacles led us to adopt an aggregation procedure, so as to reduce some potential interpretation and multicollinearity biases. We first decided, in an arbitrary way, to aggregate $A B S, B O T T$ and TOBS in a single variable named "Skills, supply or technical constraints"(TEC), since the distinction between these obstacles is not very relevant in terms of policy implications. Then, we undertook a hierarchical clustering procedure, represented in Figure 1, to further aggregate obstacles while keeping a strong explanatory power.

Figure 1 displays the way obstacles are aggregated through the clustering procedure. The horizontal axis represents the share of variance still explained after aggregating variables (taking as a benchmark the non-aggregated model). The first obstacles to be aggregated were branch and firm agreements, then workforce and union opposition. Not only these two aggregations seem intuitively relevant, they also allow explaining more than $80 \%$ of the variance associated with the non-aggregated model. We therefore decided to stop aggregating variables at this threshold, to avoid losing too much explanatory power with respect to the non-aggregated model. Table 1 summarizes the aggregation procedure outcome. 


\section{Figure 1 - Hierarchical Clustering Procedure Result}

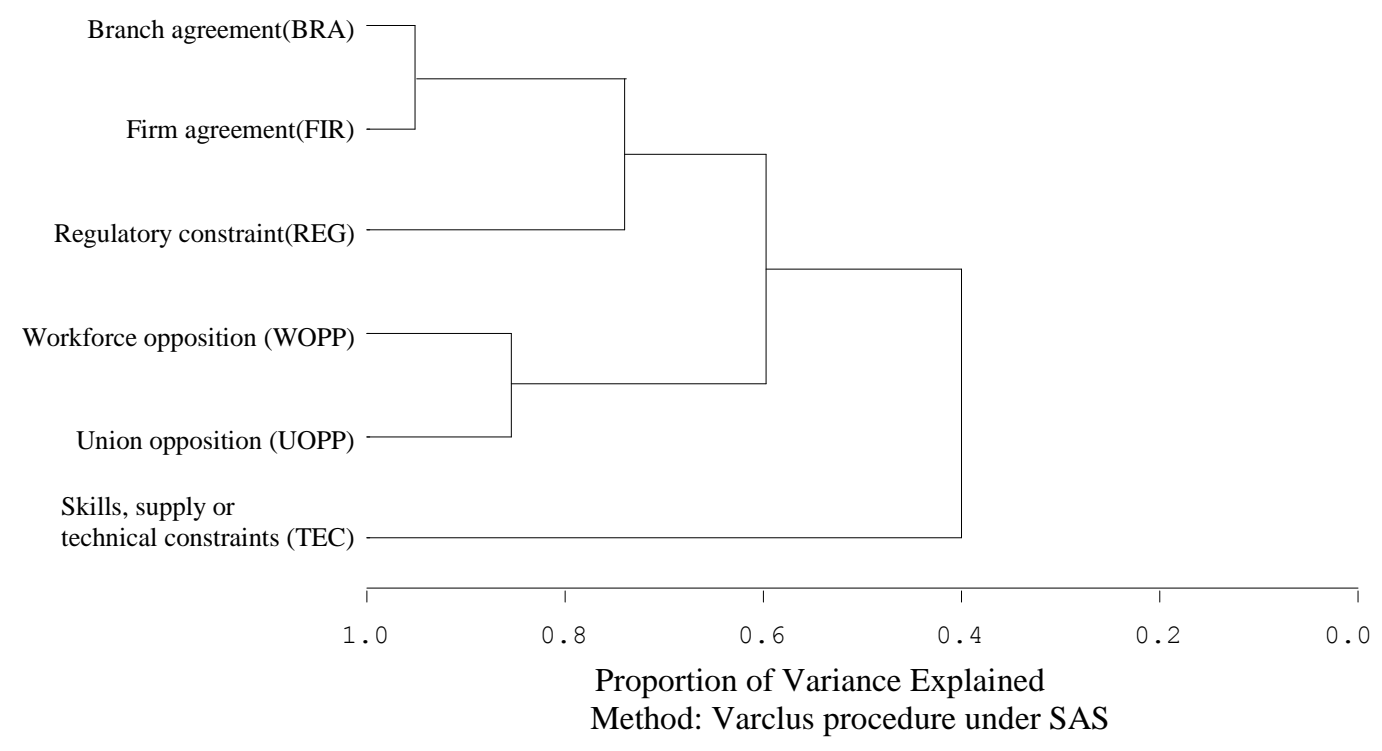

Looking at the evolution of obstacle declarations through time yields interesting insights (Figure 2). First, it appears that the different obstacles can easily be ranked in terms of reporting frequency, this hierarchy being quite stable through time.

Each year, between $40 \%$ and $70 \%$ of firms signalled the presence of skills, supply or technical constraints (TEC), which makes them the most frequently, reported obstacles. Workforce or union oppositions $(O P P)$ were signalled by nearly $45 \%$ of firms every year, while regulatory obstacles were declared by a third of firms on average (with a peak at $47 \%$ in 2001). Obstacles linked to collective agreements at the branch or firm level $(A G R)$ would be the least reported rigidities, but would nevertheless be faced by around $15 \%$ of firms every year.

Second, aside from these hierarchical considerations, we observe a kind of common trend between obstacle reporting, stemming probably from the business cycle and its perception by firms. A global increase in obstacle declarations can be highlighted between 1998 and 2001. It is easily understandable that during expansions, firms perceive constraints in a stronger way, precisely because they feel the need to increase their production and, therefore, their capital operating time. As a matter of fact, the TEC obstacle showed the strongest cyclical component over 1991-2008.

Interestingly, the larger the firm, the more frequently obstacles are declared as regards workforce or union opposition $(O P P)$ and branch or firm agreements $(A G R)$ (see Figure 3). In contrast, the smaller the firm, the more frequently entrepreneurs report obstacles linked to skills, supply or technical constraints (TEC) and regulatory constraints (REG). This tends to show that large firms have developed means to adapt technical shortages and reg- 


\section{Table 1 - Aggregation Procedure}

\begin{tabular}{|l|c|}
\hline Aggregated obstacles...* $^{*}$ & ... from originally declared obstacles \\
\hline Workforce or union opposition (OPP) & - Workforce opposition (WOPP) \\
& - Union opposition (UOPP) \\
\hline Skills, supply or technical constraints (TEC) & - Absence of qualified workforce (ABS) \\
& - Bottleneck on commodities or supply (BOTT) \\
\hline Regulatory constraint (REG) & - Technical obstacles (TOBS) \\
\hline Branch or Firm Agreement (AGR) & - Branch agreement (BRA) \\
& - Firm agreement (FIR) \\
\hline
\end{tabular}

* For instance, the OPP variable takes value 1 if workforce opposition (WOPP) and / or union opposition (UOPP) are / is declared, 0 otherwise. Other aggregates were built in the same way, from their corresponding components.

\section{Figure 2 - Obstacle Declarations Through Time}

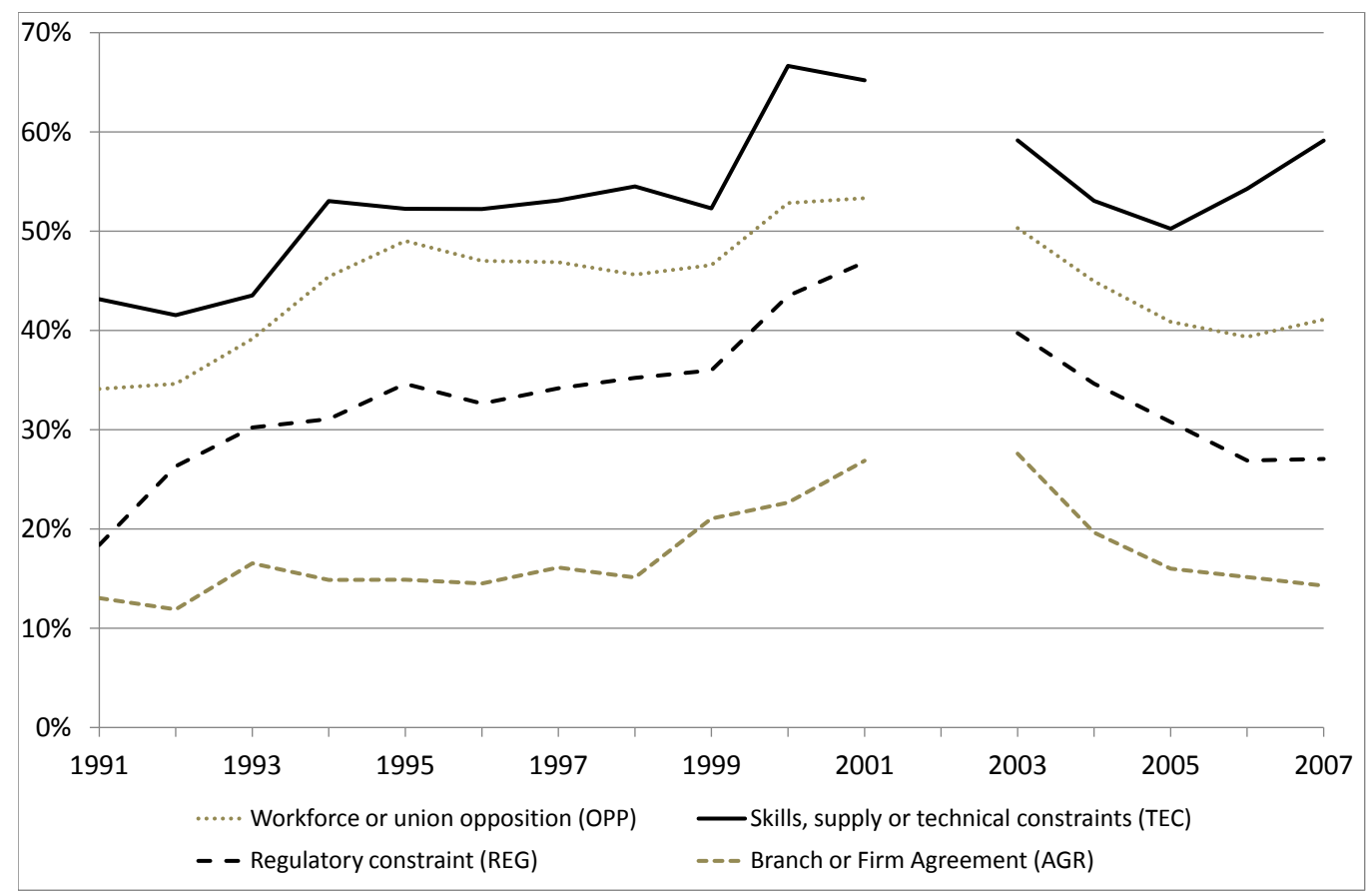

The panel is unbalanced, which may imply sample effects. 2002 is unfortunately not present in the dataset since accidentally, paper questionnaires for the 2002 survey are no longer available at the Banque de France. 


\section{Figure 3 - Obstacles Distribution by Firm Size}

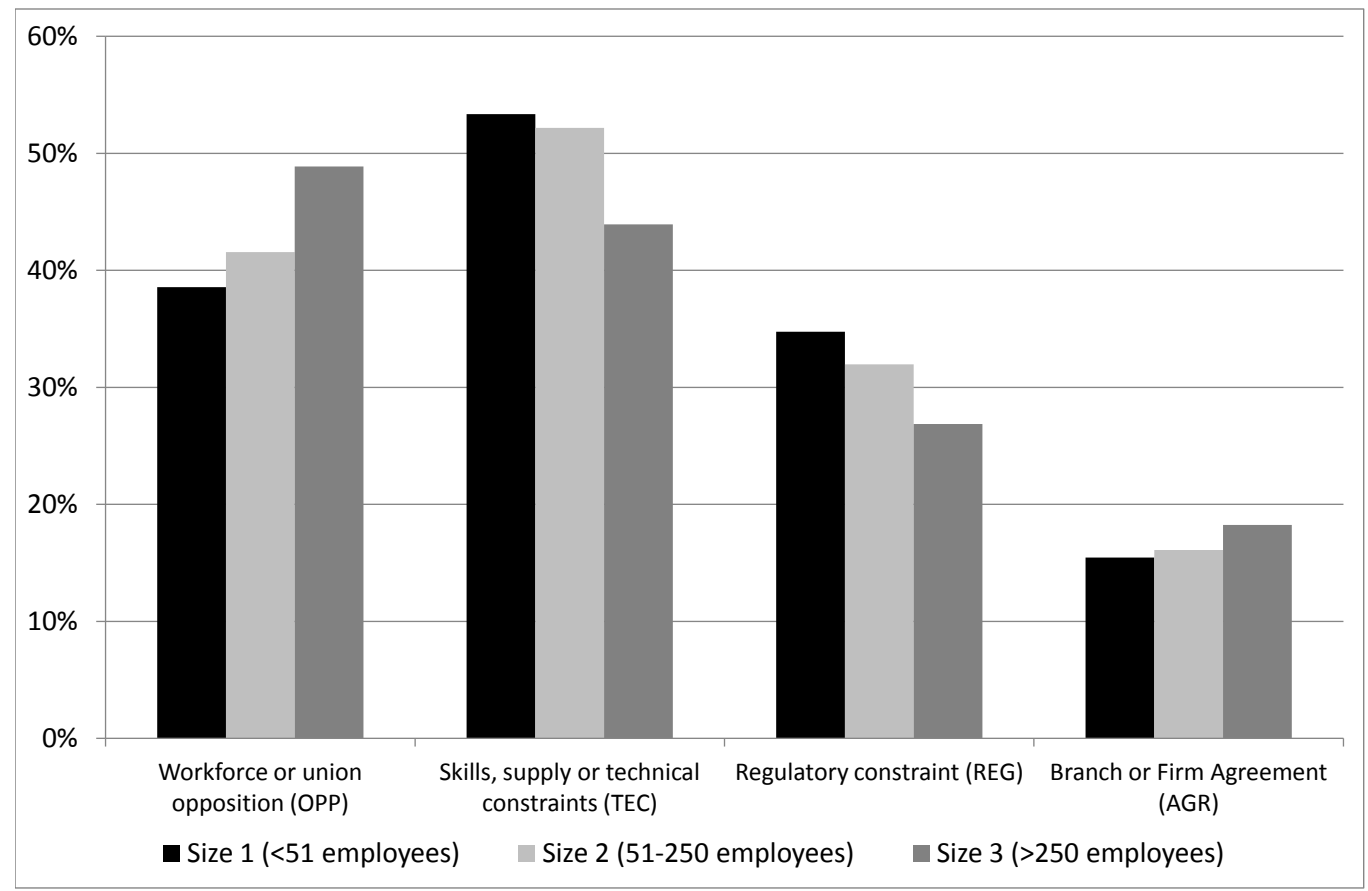

ulatory obstacles, but would suffer more than smaller firms from workers' oppositions. Small firms in France are generally operating in a less unionized environment than big firms. This may explain why their reporting of obstacles linked to workforce or union opposition, and branch or firm agreements, is lower with respect to larger firms.

Further descriptive statistics about the variables used may be found in the Appendix. We now explain and detail in the following section our empirical strategy.

\section{Empirical Methodology}

In the FUD survey, obstacles to increase capital operating time provide some rich information on the constraints that may prevent total factor productivity (TFP) improvements. In our estimations, these obstacles will therefore be used as TFP regressors, on the sub-sample of firms reporting at least one obstacle.6

6 There may be a bias in using this sub-sample as firms reporting obstacles need to increase capital operating time and hence may be in a tense production phase. To deal with this potential issue, we control for the firm-specific production cycles through its value added growth as an explanatory variable, and for the firm structural situation through firm fixed effects. The whole sample cannot be used since firms that report no obstacle may do so because they do not need to increase their capital operating time, not because they do not face any obstacle. 
Skills, supply or technical constraints (TEC) bear on human capital and on capital utilisation in the upper phase of the cycle, which will impact our TFP measure. These shortages may constrain firms to adopt some suboptimal production organisation or process, which could have an impact on TFP. Workforce or union opposition (OPP) directly bears on TFP through a lower effort from the workers, or indirectly through a resistance to reorganisations of the production process. Regulatory constraints (REG) or branch/firm agreements $(A G R)$ may hinder TFP-improving reorganisations. On the other hand, $A G R$ testifies of a significant worker involvement, alleviating information asymmetries between employees and management and reducing economic inefficiencies (Freeman and Lazear, 1995), and more globally of good labour relations quality, which can have a positive productivity impact. Indeed, unionization (Brown and Medoff, 1978) or worker voices (Fairris and Askenazy, 2010) have been shown to have a positive impact on firm productivity.

Some interactions between obstacles may be relevant. Indeed, workforce or union opposition may be more detrimental to TFP if this opposition can use regulatory constraints to prevent reorganisations of the production process $\left(O P P^{*} R E G\right)$. On the contrary, firm or branch agreements may have an ambiguous role, either acting as a kind of regulatory constraint in interaction with workers' opposition, or alleviating the degree of workforce opposition $\left(O P P^{*} A G R\right)$ and helping overcome rigidities stemming from regulation $\left(R E G^{*} A G R\right)$.

The estimated equation is the following:

$$
t f p_{i, t}=\alpha_{0}+\alpha_{1} \Delta q_{i, t}+\alpha_{2} w_{i, t}+\sum_{k=1}^{k=4} \beta_{k} O B S_{k, i, t-1}+\gamma X_{j, t}+\delta_{i}+\epsilon_{i, t}
$$

with variables:

- $t f p$ : total factor productivity (in log)

- $q$ : value added (in $\log )$

- $w$ : wages per employee (in $\log$ )

- $O B S_{k}$ : obstacles to increasing capital operating time

- $X$ : a vector of controls including sector-year dummies

- $\delta$ : firm fixed effects

- $\epsilon$ : error term

and subscripts: 
- $i$ for firm

- $j$ for industry

- $t$ for year

We use sector-year dummies to control for industry cycles and TFP trends. These dummies are also crucial to avoid estimating a spurious relationship: with an upward-trending TFP regressed on obstacles taking values 0 or 1 , year dummies are needed. Value added growth controls for potential mismeasurements of factor utilisation in the TFP regression (cf. Cette et al., 2011), firm-specific cycles or activity trends. Wages per employee control for the unmeasured quality of human capital, but also for the favourable impact of a generous wage policy on labour climate. We also use firm-specific fixed effects, which control for time-invariant firm unobserved heterogeneity such as management quality.

We may face a double causality bias: firms benefitting from high TFP may be able to provide higher wages, overcoming worker or union opposition, to better secure supply, attract talents and negotiate more favourable firm agreements by being able to provide more generous compensations for increased flexibility. In order to address this bias, we implement an instrumentation strategy based on Hansen (1982) GMM estimator using lagged obstacles levels and changes as instruments. Changes in value added may be endogenous and are also instrumented the same way. We also use instruments reflecting the transition to the 35-hour week, that is to say both a dummy for the expected transition to a 35-hour week from the same survey as well as lagged changes in working time. Then, we use a dummy reflecting the fact that workers benefit from profit-sharing scheme as it may induce workers to subscribe more to managers' decisions and may reflect more interactive management techniques (although profit-sharing schemes are compulsory for firms above 50 employees). As we may face heteroscedasticity and serial correlation, we use the generalised method of moments with robust standard errors.

\section{Results}

The main estimates are presented in Table 2. It is noteworthy to emphasise that OLS results are consistent with 2SLS ones in terms of sign if not significance.

Value added growth has a positive and significant impact on the TFP level, with stable coefficients, around 0.28 for 2SLS estimates (columns 2 and 4). This result, usually found in empirical studies, indicates the existence of short-term increasing returns to production factors. Cette et al. (2011) argue they can be due to omitted variables, particularly the intensity of factor utilisation. With the very same dataset, they show how increasing returns 
Table 2 - Main Results

\begin{tabular}{|c|c|c|c|c|}
\hline & $\begin{array}{c}\text { (1) } \\
\text { Without } \\
\text { interactions }\end{array}$ & $\begin{array}{c}(2) \\
\text { Without } \\
\text { interactions - 2SLS }\end{array}$ & $\begin{array}{c}\text { (3) } \\
\text { With } \\
\text { interactions }\end{array}$ & $\begin{array}{c}\text { (4) } \\
\text { With interactions } \\
-2 S L S\end{array}$ \\
\hline$\Delta$. Value added (log) & $\begin{array}{l}0.526 * * * \\
(0.00970)\end{array}$ & $\begin{array}{c}0.285^{* * *} \\
(0.0226)\end{array}$ & $\begin{array}{l}0.527 * * * \\
(0.00970)\end{array}$ & $\begin{array}{c}0.280^{* * *} \\
(0.0228)\end{array}$ \\
\hline Wage per head (log) & $\begin{array}{l}0.224 * * * \\
(0.0147)\end{array}$ & $\begin{array}{l}0.264 * * * \\
(0.0327)\end{array}$ & $\begin{array}{c}0.225^{* * *} \\
(0.0147)\end{array}$ & $\begin{array}{c}0.259 * * * \\
(0.0328)\end{array}$ \\
\hline Worforce or union opposition ( $\mathrm{OPP}_{-1}$ ) & $\begin{array}{l}-0.00909 * \\
(0.00480)\end{array}$ & $\begin{array}{l}-0.0209 * * \\
(0.00917)\end{array}$ & $\begin{array}{l}-0.00150 \\
(0.00603)\end{array}$ & $\begin{array}{c}0.00408 \\
(0.00803)\end{array}$ \\
\hline Skills, supply or technical constraints (TEC ${ }_{-1}$ ) & $\begin{array}{c}0.00576 \\
(0.00449)\end{array}$ & $\begin{array}{c}0.0330 \\
(0.0278)\end{array}$ & $\begin{array}{c}0.00438 \\
(0.00454)\end{array}$ & $\begin{array}{c}-0.00570 \\
(0.00736)\end{array}$ \\
\hline Regulatory constraints (REG-1) & $\begin{array}{c}0.00594 \\
(0.00491)\end{array}$ & $\begin{array}{c}0.00607 \\
(0.00806)\end{array}$ & $\begin{array}{c}0.00702 \\
(0.00725)\end{array}$ & $\begin{array}{c}0.0124 \\
(0.0106)\end{array}$ \\
\hline Branch or firm agreement $\left(\mathrm{AGR}_{-1}\right)$ & $\begin{array}{c}-0.00906 \\
(0.00585)\end{array}$ & $\begin{array}{c}-0.0144 \\
(0.0102)\end{array}$ & $\begin{array}{r}-0.00674 \\
(0.0132)\end{array}$ & $\begin{array}{l}-0.0506 \\
(0.0323)\end{array}$ \\
\hline $\begin{array}{l}\text { Worforce or union opposition and regulatory } \\
\text { constraints (OPP }-1 \text { X REG }_{-1} \text { ) }\end{array}$ & & & $\begin{array}{l}-0.00994 \\
(0.00949)\end{array}$ & $\begin{array}{r}-0.0214^{*} \\
(0.0121)\end{array}$ \\
\hline $\begin{array}{l}\text { Worforce or union opposition and branch or } \\
\text { firm agreement }\left(\mathrm{OPP}_{-1} \times \mathrm{AGR}_{-1}\right)\end{array}$ & & & $\begin{array}{l}-0.0216^{*} \\
(0.0128)\end{array}$ & $\begin{array}{c}0.0107 \\
(0.0238)\end{array}$ \\
\hline $\begin{array}{l}\text { Regulatory constraints and branch or firm } \\
\text { agreement } \\
\left(\mathrm{REG}_{-1} \mathrm{XAGR}_{-1}\right)\end{array}$ & & & $\begin{array}{l}0.0217^{*} \\
(0.0120)\end{array}$ & $\begin{array}{c}0.0426 * * \\
(0.0208)\end{array}$ \\
\hline $\mathrm{N}^{\circ}$ Observations & 7,441 & 7,441 & 7,441 & 7,441 \\
\hline Adj. $R^{2}$ & 0.222 & 0.223 & 0.222 & 0.222 \\
\hline Sargan-Hansen & & 18.87 & & 10.35 \\
\hline Sargan-Hansen p-value & & 0.275 & & 0.323 \\
\hline
\end{tabular}

Robust standard errors in parentheses; ${ }^{*} p<0.1,{ }^{* *} p<0.05,{ }^{* * *} p<0.01$.

Firm fixed effects, two stage least square estimates when specified, generalized method of moments. Lagged difference of working time, lagged dummy for transition expected to the 35-hour week, lagged dummy for worker benefitting from profit-sharing schemes (participation des salariés aux résultats de l'entreprise), lagged levels and lagged difference of obstacles used as instruments. Sector * Year dummies and constant included but not reported. 
to scale disappear when working time, capacity utilisation rate and mainly capital operating time are introduced in the production function. The use of value added growth as well as sector-year dummies is also helpful to neutralize the effects of general or firm-specific demand conditions on TFP, so to avoid any spurious correlation with the stationary survey answers on obstacles. 'Wages per employee' has a positive and significant impact on the TFP level, with quite stable coefficients, around 0.26 for 2SLS estimates (columns 2 and 4), which is consistent with the literature. 'Skills, supply or technological constraints' have no significant impact on the TFP level, which may not be surprising. Shortages may constrain firms to adopt a non-optimal production organisation or process, which could decrease or increase, depending on the situation, the TFP level compared to a situation without such shortages. For example, a shortage in labour or capital may lead to a more intensive use of the available quantity of these two factors, and increase TFP. Moreover, as this obstacle is reported by many firms throughout the period (cf. Figure 2), its impact may be captured by firm fixed effects as it may reflect the usual recruitment policy or supply management of the firm.

Without taking into account the potential interactions between explanatory variables (columns 1 and 2), 'workforce or union opposition' is the only obstacle which would have a significant impact on productivity. The existence of such an opposition would decrease TFP by around $2 \%$ (column 2). 'Regulatory constraints' do not have a significantly negative direct impact on productivity. Nonetheless, it appears (columns 3 and 4) that these regulatory constraints do have a negative impact on TFP when 'workforce or union opposition' are reported, leading to a $-2 \%$ decrease in TFP on average (column 4). This suggests that 'regulatory constraints' would only become significantly binding when workers or unions use them as a tool to oppose management decisions. For example, working time rules are complex and workers or unions, through the threat of legal procedure, may lead to a stricter application of these rules in cases of deteriorated labour relations.

Besides, 'branch or firm agreement' has no direct impact on TFP (columns 1 to 4) but the interaction between 'branch and firm agreement' and 'regulatory constraints' has a positive and significant impact (columns 3 and 4). These puzzling results can receive two explanations. First, a branch or firm collective agreement can organize efficient working organisations, thus alleviating regulatory constraints. Secondly, the French labour code allows softening specified regulatory constraints through a collective agreement. This was emphasised in the context of the 35-hour workweek policy implemented in France from 1998, after the left-wing electoral victory of 19977 This policy consisted in a decrease from 39 to 35 hours, in 2000 for firms of more than 20 employees (which represent more than $97 \%$ of our sample)

7 The 35-hour workweek policy change is captured in our analysis by the year fixed-effect. 
Table 3 - Separating Branch and Firm Agreements

\begin{tabular}{|c|c|c|c|c|}
\hline & $\begin{array}{c}\text { (1) } \\
\text { Without interactions }\end{array}$ & $\begin{array}{c}\text { (2) } \\
\text { Without } \\
\text { interactions 2SLS }\end{array}$ & $\begin{array}{c}\text { (3) } \\
\text { With interactions }\end{array}$ & $\begin{array}{c}\text { (4) } \\
\text { With } \\
\text { interactions } 2 \mathrm{SLS}\end{array}$ \\
\hline$\Delta$. Value added (log) & $\begin{array}{l}0.526^{* * *} \\
(0.00970)\end{array}$ & $\begin{array}{l}0.285^{* * *} \\
(0.0226)\end{array}$ & $\begin{array}{l}0.527^{* * *} \\
(0.00971)\end{array}$ & $\begin{array}{l}0.283^{* * *} \\
(0.0226)\end{array}$ \\
\hline Wage per head (log) & $\begin{array}{l}0.225^{* * *} \\
(0.0147)\end{array}$ & $\begin{array}{l}0.264^{* * *} \\
(0.0326)\end{array}$ & $\begin{array}{l}0.225^{* * *} \\
(0.0147)\end{array}$ & $\begin{array}{l}0.263^{* * *} \\
(0.0328)\end{array}$ \\
\hline $\begin{array}{l}\text { Workforce or union opposition } \\
\left(\mathrm{OPP}_{-1}\right)\end{array}$ & $\begin{array}{l}-0.00934^{*} \\
(0.00487)\end{array}$ & $\begin{array}{l}-0.0225^{* *} \\
(0.00966)\end{array}$ & $\begin{array}{l}-0.00204 \\
(0.00602)\end{array}$ & $\begin{array}{c}0.00472 \\
(0.00777)\end{array}$ \\
\hline $\begin{array}{l}\text { Skills, supply or technical } \\
\text { constraints }\left(\mathrm{TEC}_{-1}\right)\end{array}$ & $\begin{array}{c}0.00620 \\
(0.00451)\end{array}$ & $\begin{array}{c}0.0442 \\
(0.0333)\end{array}$ & $\begin{array}{l}0.00463 \\
(0.00461)\end{array}$ & $\begin{array}{l}-0.00691 \\
(0.00757)\end{array}$ \\
\hline Regulatory constraints (REG ${ }_{-1}$ ) & $\begin{array}{c}0.00644 \\
(0.00503)\end{array}$ & $\begin{array}{c}0.00599 \\
(0.00843)\end{array}$ & $\begin{array}{c}0.00850 \\
(0.00729)\end{array}$ & $\begin{array}{c}0.0147 \\
(0.0103)\end{array}$ \\
\hline Branch agreement (BRA $\left.{ }_{-1}\right)$ & $\begin{array}{c}-0.0103 \\
(0.00794)\end{array}$ & $\begin{array}{l}-0.0168 \\
(0.0106)\end{array}$ & $\begin{array}{l}-0.0131 \\
(0.0198)\end{array}$ & $\begin{array}{l}-0.0251 \\
(0.0571)\end{array}$ \\
\hline Firm agreement $\left(\mathrm{FIR}_{-1}\right)$ & $\begin{array}{r}-0.000200 \\
(0.00769)\end{array}$ & $\begin{array}{c}-0.00298 \\
(0.00985)\end{array}$ & $\begin{array}{l}0.00927 \\
(0.0167)\end{array}$ & $\begin{array}{l}-0.0610 \\
(0.0403)\end{array}$ \\
\hline $\mathrm{OPP}_{-1} \times \mathrm{REG}_{-1}$ & & & $\begin{array}{c}-0.0114 \\
(0.00981)\end{array}$ & $\begin{array}{l}-0.0240^{*} \\
(0.0137)\end{array}$ \\
\hline $\mathrm{OPP}_{-1} \times \mathrm{BRA}_{-1}$ & & & $\begin{array}{l}-0.0108 \\
(0.0171)\end{array}$ & $\begin{array}{c}-0.00572 \\
(0.0329)\end{array}$ \\
\hline $\mathrm{OPP}_{-1} \times \mathrm{FIR}_{-1}$ & & & $\begin{array}{c}-0.0263 \\
(0.0177)\end{array}$ & $\begin{array}{c}0.0347 \\
(0.0348)\end{array}$ \\
\hline $\mathrm{REG}_{-1} \times \mathrm{BRA}_{-1}$ & & & $\begin{array}{c}0.0103 \\
(0.0185)\end{array}$ & $\begin{array}{c}0.0140 \\
(0.0417)\end{array}$ \\
\hline $\mathrm{REG}_{-1} \times \mathrm{FIR}_{-1}$ & & & $\begin{array}{c}0.0245 \\
(0.0162)\end{array}$ & $\begin{array}{l}0.0478^{* *} \\
(0.0200)\end{array}$ \\
\hline $\mathrm{N}^{\circ}$ Observations & 7,441 & 7,441 & 7,441 & 7,441 \\
\hline Adj. $R^{2}$ & 0.222 & 0.219 & 0.222 & 0.222 \\
\hline Sargan-Hansen & & 18.21 & & 16.35 \\
\hline Sargan-Hansen p-value & & 0.252 & & 0.176 \\
\hline
\end{tabular}

Robust standard errors in parentheses; ${ }^{*} p<0.1,{ }^{* \star} p<0.05,{ }^{* \star *} p<0.01$.

Firm fixed effects, two stage least square estimates when specified, generalized method of moments. Lagged difference of working time, lagged dummy for transition expected to the 35-hour week, lagged dummy for worker benefitting from profit-sharing schemes (participation des salariés aux résultats de lâentreprise), lagged levels and lagged difference of obstacles used as instruments. Sector * Year dummies and constant included but not reported. 
and in 2002 for other firms, of the legal weekly working time threshold from which firms have to pay an overtime wage premium. For a firm decreasing to 35 hours or less the usual weekly working time of its employees, it was possible to get generous financial subsidies from the State if this decrease was organised through a collective agreement between social partners, at the firm level for firms of more than 50 employees and also possibly at the branch level for other firms. To get these subsidies, the agreements had to be signed by unions representing at least $50 \%$ of the employee votes at union elections. But the 35 hour workweek laws allowed firms to implement through a collective agreement some flexible labour organisation with a possible positive impact on TFP. For instance, it was possible through agreements to exclude some breaks of the accounted working time, or to account daily rather than hourly the working time for white collars, or to respect the 35 hours threshold in average over the year or even in average over several years. But the use of these disposals needed good quality labour relations, employee unions having the choice not to allow it. The results also indicate that 'branch or firm agreement' would have offset the significant negative impact of the interaction between 'regulatory constraints' and 'work force or union opposition', as it yields a positive impact of $4 \%$ on TFP. The interaction between 'branch or firm agreement' and 'work force or union opposition' is not significant when instrumented: indeed, 'branch or firm agreement' may actually be alleviating 'work force or union opposition' and hence neutralising its impact.

Table 3 displays estimates where branch and firm agreements are separated. It is difficult to identify separately both types of agreements which are highly correlated but it appears that the positive interacted impact of 'agreements' with 'regulatory constraints' would result mostly from 'firm agreements' rather than 'branch agreements' (Table 3, column 4). This result indicates that it is mainly at the firm level that good quality labour relations can allow to use some complex regulation disposals to improve the firm's productive performance.

These results support the role of labour relations quality, mainly at the firm level, as a powerful factor of productive performance. They provide an original confirmation to early insights in the literature (e.g. Freeman and Lazear, 1995). 


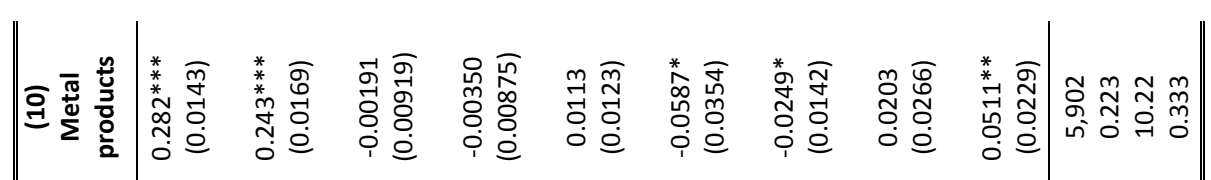

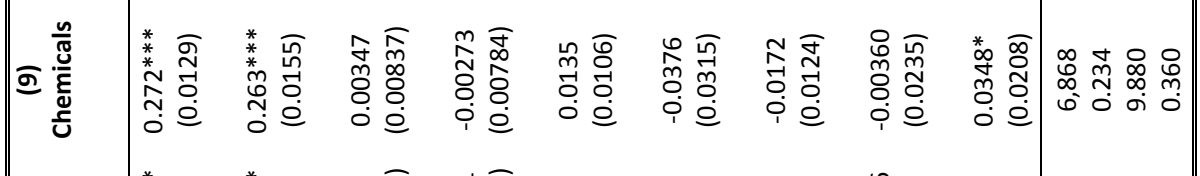

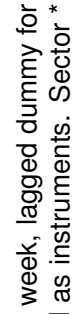

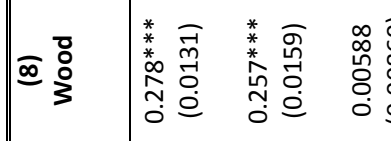

范

0
0
0
0
0
0

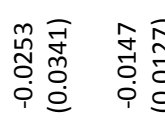

空

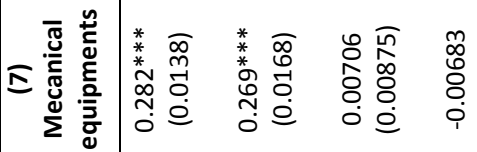

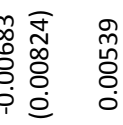

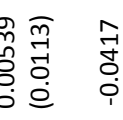

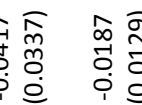

ब्ञ

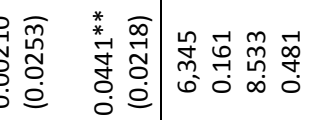

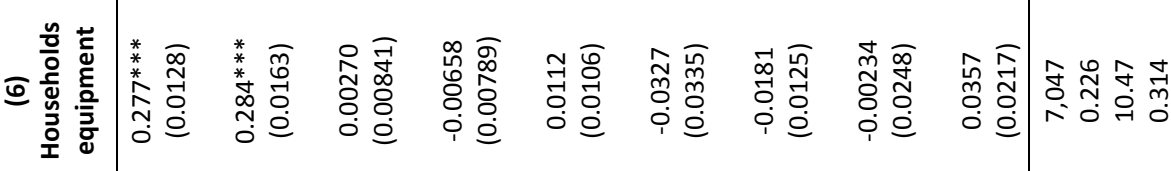

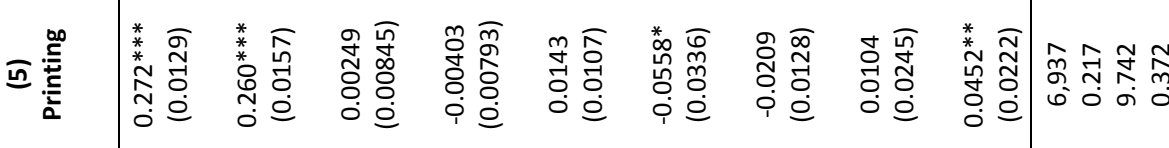

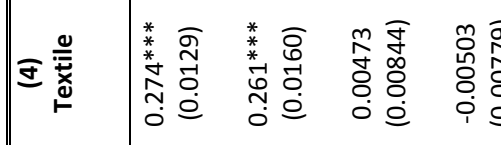

$m$
0
0
0
0
0
0

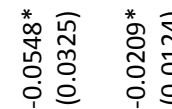

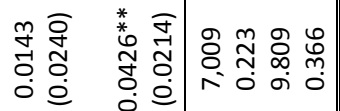

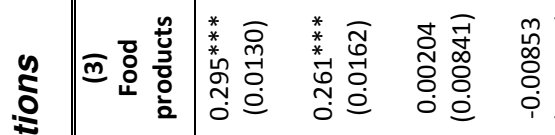

\section{홍}

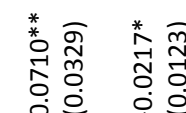

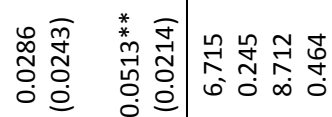

호웡

官 \&

$\stackrel{8}{\rightleftarrows} \frac{\pi}{5}$

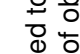

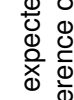

은

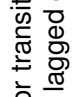

흔

हो

응

즐

$\stackrel{\Phi}{\oplus}$

कृ

30

o

d)

ป ช

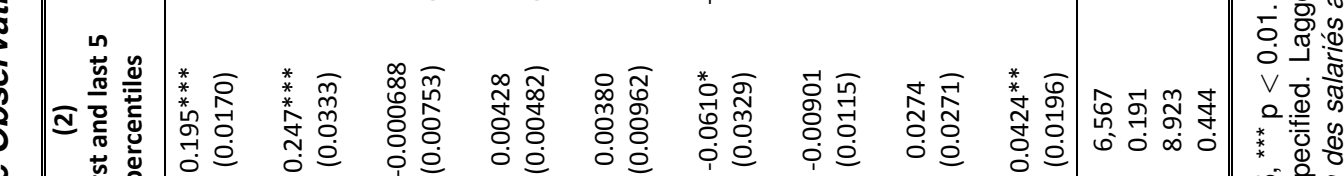

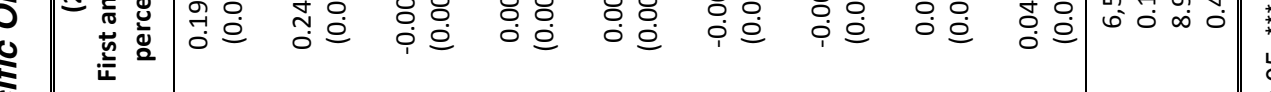

के

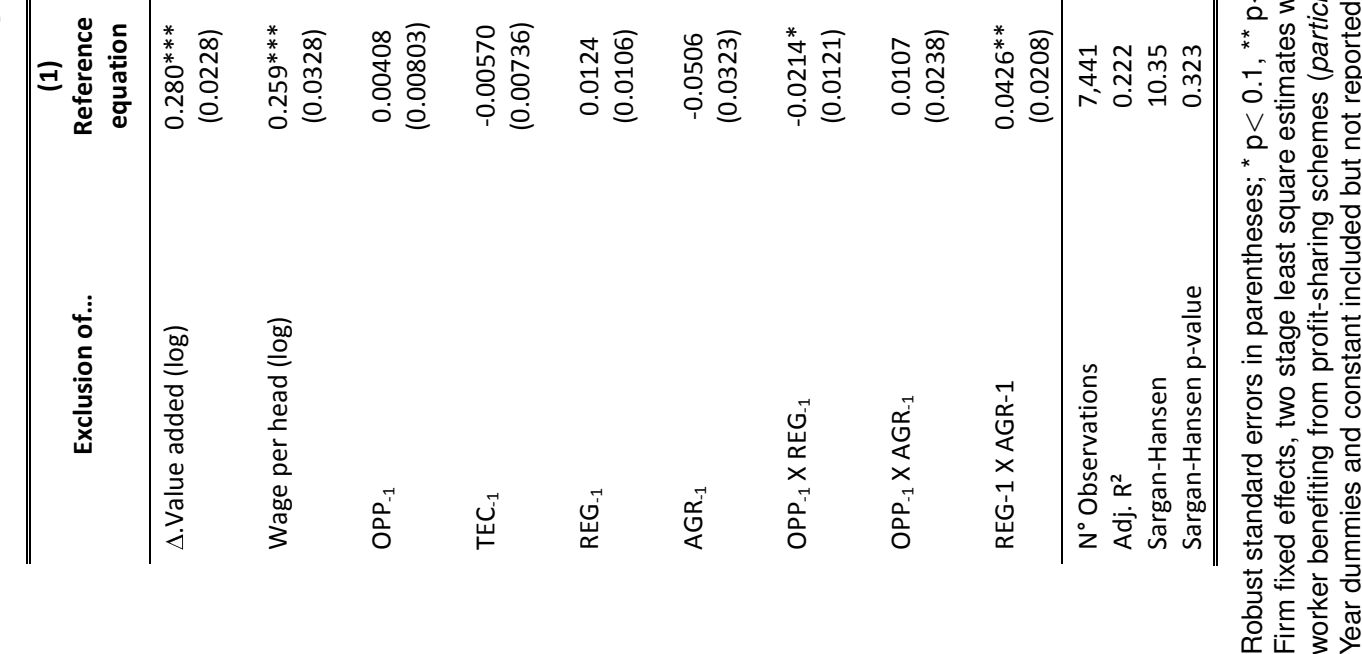


Table 5 - Robustness to Alternative Specification

\begin{tabular}{|c|c|c|c|c|}
\hline & $\begin{array}{c}\text { (1) } \\
\text { Reference } \\
\text { Equation }\end{array}$ & $\begin{array}{c}\text { (2) } \\
\text { Without year X } \\
\text { sector dummies }\end{array}$ & $\begin{array}{c}\text { (3) } \\
\text { Without } \Delta \text { value } \\
\text { added }\end{array}$ & $\begin{array}{c}\text { (4) } \\
\text { without } \\
\text { wages }\end{array}$ \\
\hline$\Delta$. Value added (log) & $\begin{array}{l}0.280^{* * *} \\
(0.0228)\end{array}$ & $\begin{array}{l}0.276^{* * *} \\
(0.0238)\end{array}$ & - & $\begin{array}{l}0.291^{* * *} \\
(0.0227)\end{array}$ \\
\hline Wage per head (log) & $\begin{array}{l}0.259^{* * *} \\
(0.0328)\end{array}$ & $\begin{array}{l}0.270^{* * *} \\
(0.0366)\end{array}$ & $\begin{array}{l}0.305^{* * *} \\
(0.0354)\end{array}$ & - \\
\hline Worforce or union opposition ( $\mathrm{OPP}_{-1}$ ) & $\begin{array}{c}0.00408 \\
(0.00803)\end{array}$ & $\begin{array}{c}0.00296 \\
(0.00870)\end{array}$ & $\begin{array}{c}0.00293 \\
(0.00925)\end{array}$ & $\begin{array}{c}0.00234 \\
(0.00823)\end{array}$ \\
\hline Skills, supply or technical constraints (TEC -1 ) & $\begin{array}{l}-0.00570 \\
(0.00736)\end{array}$ & $\begin{array}{l}-0.00266 \\
(0.00780)\end{array}$ & $\begin{array}{l}-0.00226 \\
(0.00857)\end{array}$ & $\begin{array}{l}-0.00584 \\
(0.00756)\end{array}$ \\
\hline Regulatory constraints $\left(\mathrm{REG}_{-1}\right)$ & $\begin{array}{c}0.0124 \\
(0.0106)\end{array}$ & $\begin{array}{c}0.0129 \\
(0.0117)\end{array}$ & $\begin{array}{c}0.0123 \\
(0.0124)\end{array}$ & $\begin{array}{c}0.0111 \\
(0.0109)\end{array}$ \\
\hline Branch or firm agreement $\left(\mathrm{AGR}_{-1}\right)$ & $\begin{array}{l}-0.0506 \\
(0.0323)\end{array}$ & $\begin{array}{l}-0.0588^{*} \\
(0.0350)\end{array}$ & $\begin{array}{l}-0.0632^{*} \\
(0.0375)\end{array}$ & $\begin{array}{l}-0.0547^{*} \\
(0.0329)\end{array}$ \\
\hline $\begin{array}{l}\text { Worforce or union opposition and regulatory } \\
\text { constraints }\left(\mathrm{OPP}_{-1} \mathrm{XREG}_{-1} \text { ) }\right.\end{array}$ & $\begin{array}{l}-0.0214^{*} \\
(0.0121)\end{array}$ & $\begin{array}{l}-0.0262^{*} \\
(0.0141)\end{array}$ & $\begin{array}{l}-0.0214 \\
(0.0141)\end{array}$ & $\begin{array}{l}-0.0210^{*} \\
(0.0125)\end{array}$ \\
\hline $\begin{array}{l}\text { Worforce or union opposition and branch or firm } \\
\text { agreement }\left(\mathrm{OPP}_{-1} \mathrm{X} \mathrm{AGR}_{-1}\right)\end{array}$ & $\begin{array}{c}0.0107 \\
(0.0238)\end{array}$ & $\begin{array}{l}0.00302 \\
(0.0235)\end{array}$ & $\begin{array}{c}0.0229 \\
(0.0274)\end{array}$ & $\begin{array}{c}0.0143 \\
(0.0242)\end{array}$ \\
\hline $\begin{array}{l}\text { Regulatory constraints and branch or firm } \\
\text { agreement }\left(\mathrm{REG}_{-1} \times \mathrm{XGR}_{-1}\right)\end{array}$ & $\begin{array}{l}0.0426^{* *} \\
(0.0208)\end{array}$ & $\begin{array}{l}0.0651^{*} \\
(0.0392)\end{array}$ & $\begin{array}{l}0.0427^{*} \\
(0.0243)\end{array}$ & $\begin{array}{l}0.0432^{* *} \\
(0.0213)\end{array}$ \\
\hline $\mathrm{N}^{\circ}$ Observations & 7,441 & 7,441 & 7,441 & 7,441 \\
\hline Adj. $R^{2}$ & 0.222 & 0.132 & -0.0673 & 0.188 \\
\hline Sargan-Hansen & 10.35 & 16.70 & 4.574 & 6.562 \\
\hline Sargan-Hansen $p$-value & 0.323 & 0.272 & 0.600 & 0.363 \\
\hline
\end{tabular}

Robust standard errors in parentheses; ${ }^{*} p<0.1,{ }^{* *} p<0.05,{ }^{* * *} p<0.01$.

Firm fixed effects, two stage least square estimates, generalized method of moments. Lagged difference of working time, lagged dummy for transition expected to the 35-hour week, lagged dummy for worker benefiting from profit-sharing schemes (participation des salaries aux résultats de l'entreprise), lagged levels and lagged difference of obstacles used as instruments. Sector * Year dummies when specified and constant included but not reported.

\section{Robustness Checks}

Our flagship result is the structural regression in Table 2, column 4, which emphasises the role of interactions between regulatory constraints, branch or firm agreements, and employee or union opposition. In Table 4, we present several robustness checks for this regression, on different subsamples. First, we exclude firms for which TFP level lies in the first or last 5 percentiles. That way, we assess whether our results are driven by a small number of extreme observations. The coefficient signs are not altered, although their significance changes: $R E G$ * $A G R$ is still significant, but $O P P$ * $R E G$ is not. Then, we exclude one by one all sectors representing more than $5 \%$ of the sample, to evaluate the sensitivity of our results to specific activities (although we already had firm fixed effects and year-industry dummies in the reference equation). Significance and magnitude of the coefficients are barely altered, especially for $R E G^{*} A G R$. $O P P{ }^{*} R E G$ is however not sig- 
nificant for a large number of subsamples.

We provide in Table 5 further robustness estimates with different specifications.

We remove year*sector dummies (column 1), while keeping year dummies which are necessary to avoid a spurious regression of a time series $(T F P)$ on stationary variables. Our main results are not altered: $R E G^{*} A G R$ and $O P P^{*} R E G$ keep the same signs significance and magnitude. The magnitude is stronger for $R E G^{*} A G R$, although less precise.

We remove the firm production cycle control,. $\Delta V A$ Indeed, this control may encompass a lot of relationships beyond the firm production cycle (in particular supply shocks due to our variables of interest). Coefficients in the reference equation are not altered in their signs or magnitude, but $O P P^{*} R E G$ is no longer significant.

We remove the control for wage per head, which may be collinear with labour relations. Coefficients are practically unaltered in signs or significance.

Our main result, showing that the negative effect of regulatory constraints on productivity can be alleviated by branch or firm agreements, appears to be fairly robust. However, the fact that regulatory constraints may be more stringent when employees or unions use them to prevent TFP improvements tends to be non-significant under some robustness checks, although the sign and magnitude of this effect is unaltered.

\section{Conclusion}

Our aim was to analyse the impact on productivity of good labour relations. We have used an original database containing 7,441 observations, corresponding to 1,545 French companies, over 1991-2008. To our knowledge, this company-level database is unique in allowing such an analysis. We assume the existence of a collective agreement (at the branch or the firm level) to be a proxy for good labour relations.

The main results from our empirical investigation are the following: i) 'workforce or union opposition' interacted with 'regulatory constraints' has a negative significant impact on total factor productivity (TFP). Regulatory constraints would become really binding when workers or unions use them as a tool to oppose management's decisions; ii) 'regulatory constraints' interacted with 'branch or firm agreement' has a positive significant impact on TFP. These agreements, which can only be obtained if labour relations are supportive, would be used by firms to offset the negative impact of regulatory constraints. These results support the importance of labour relations quality and provide an original confirmation to early insights in the literature.

Nevertheless, we must remain cautious in generalising these results, since France is a particular country regarding labour relations. Among 
OECD countries, France has the lowest union membership rate. It is probably the country (or at least one of the countries) where labour market regulations are the most stringent and where collective bargaining processes are the poorest and the weakest. Labour relations get conflicting faster than in other countries, and lead more easily to strikes for example. In such circumstances, the ability to conclude a collective agreement may probably be a stronger indicator of good labour relations in France than anywhere else. We cannot exclude that the impact of collective agreements, taken as a proxy of good labour relations, could have a positive but lower impact on productivity in other countries. To be generalized, our results would need to be confirmed on a database covering other countries. 


\section{References}

Addison, J.T., 2005. The Determinants of Firm Performance: Unions, Works Councils, and Employee Involvement/High-Performance Work Practices. Scottish Journal of Political Economy 52, 406-450. doi:10.1111/j.00369292.2005.00351.x

Addison, J.T., Schnabel, C., Wagner, J., 2001. Works Councils in Germany: their Effects on Establishment Performance. Oxford Economic Papers 53, 659-694. doi :10.1093/oep/53.4.659

Addison, J.T., Siebert, S., Wagner, J., Xiangdong, W., 2000. Worker Participation and Firm Performance: Evidence from Germany and Britain. British Journal of Industrial Relations 38, 7-48. doi:10.1111/1467-8543.00150

Aghion, P., Algan, Y., Cahuc, P., 2011. Civil Society and the State: The Interplay Between Cooperation and Minimum Wage Regulation. Journal of the European Economic Association 9, 3-42. doi:10.1111/j.15424774.2010.01004.x

Black, S., Lynch, L.M., 2001. How to Compete: The Impact of Workplace Practices and Information Technology on Productivity. Review of Economics and Statistics 83, 434-445. doi:10.1162/00346530152480081

Brown, C., Medoff, J.L., 1978. Trade Unions in the Production Process. Journal of Political Economy 86, 355-378. doi:10.1086/260677

Cardona, D., Sánchez-Losada, F., 2006. Unions, Qualification Choice, and Output. Oxford Economic Papers 58, 50-76. doi:10.1093/oep/gpi038

Cette, G., Dromel, N., Lecat, R., Paret, A-C., 2011. Production Factor Returns: The Role of Factor Utilisation. Banque de France Working Paper $\mathrm{n}^{\circ} 317$.

Clark, K.B., 1984. Unionization and Firm Performance: The Impact on Profits, Growth, and Productivity. American Economic Review 74, 893-919.

Cooke, W.N., 1994. Employee Participation Programmes, Group-Based Incentives, and Company Performance: a Union-Nonunion Comparison. Industrial and Labor Relations Review 47, 594-609. doi:10.2307/2524660

Deery, S.J., Iverson, R.D., 2005. Labor-Management Cooperation: Antecedents and Impact on Organisational Performance. Industrial and Labor Relations Review 58, 588-609.

Fairris, D., Askenazy, P., 2010. Works Councils and Firm Productivity in France. Journal of Labor Research 31, 209-229. doi:10.1007/s12122-0109088-z 
Freeman, R.B., Lazear, E.P., 1995. An Economic Analysis of Works Councils. In Rogers, J., Streeck, W. (Eds.). Works Councils, Consultation, Representation and Cooperation in Industrial Relations. University of Chicago Press, Chicago, pp.27-50.

Hansen, L.P., 1982. Large Sample Properties of Generalized Method of Moments Estimators. Econometrica 50,1029-1054. doi:10.2307/1912775

Hirsch, B.T., 2007. What Do Unions Do for Economic Performance? In Bennet, J.T., Kaufman, B.E. (Eds.), What Do Unions Do? Transaction Publishers, pp. 193-237.

Hübler, O., Jirjahn, U., 2003. Works Councils and Collective Bargaining in Germany: the Impact on Productivity and Wages. Scottish Journal of Political Economy 50, 471-91. http://dx.doi.org/10.1111/1467-9485.5004006

Ichniowski, C., 1986. The Effects of Grievance Activity on Productivity. Industrial and Labor Relations Review 40, 75-89. http://dx.doi.org/10.2307/2523947

Jirjahn, U., Mueller, S., 2012. Non-Union Representation, Foreign Owners, and the Performance of Establishments. Oxford Economic Papers. http://dx.doi.org/10.1093/oep/gps047

Katz, H., Kochan, T.A., Keefe, J., 1987. Industrial Relations and Productivity in the U.S. Automobile Industry. Brookings Papers on Economic Activity 3, 685-715. http:/ /dx.doi.org/10.2307/2534452

Katz, H., Kochan, T.A., Gobeille, K.R., 1983. Industrial Relations Performance, Economic Performance, and QWL Programs: An Interplant Analysis. Industrial and Labor Relations Review 37, pp. 3-17. http://dx.doi.org/10.2307/2522720

Kleiner, M., Leonard, J.S., Pilarski, A.M., 2002. How Industrial Relations Affects Plant Performance: The Case of Commercial Aircraft Manufacturing. Industrial and Labor Relations Review 55, 195-218 http://dx.doi.org/10.2307/2696205

Mas, A., 2008. Labor Unrest and the Quality of Production: Evidence from the Construction Equipment Resale Market. Review of Economic Studies 75, 229-258. http://dx.doi.org/10.1111/j.1467-937X.2007.00461.x

Moreton, D., 1999. A Model of Labour Productivity and Union Density in British Private Sector Unionised Establishments. Oxford Economic Papers 51, 322-344. http://dx.doi.org/10.1093/oep/51.2.322

Morikawa, M., 2010. Labor Unions and Productivity: An Empirical Analysis Using Japanese Firm-Level Data. Labour Economics 17, 1030-1037. http://dx.doi.org/10.1016/j.labeco.2010.02.009

OCDE (2009), Measuring Entrepreneurship. 


\section{Appendix}

Descriptive Statistics FiBEn FUD (Factor Utilisation Degrees) survey

\begin{tabular}{|c|c|c|c|c|c|c|c|c|c|}
\hline Variable & Description & Source & p10 & Q1 & Median & Q3 & P90 & Mean & $\begin{array}{l}\text { Standard } \\
\text { Deviations }\end{array}$ \\
\hline OPP & Worker or union opposition & FUD survey & 0 & 0 & 0 & 1 & 1 & 0,43 & 0,49 \\
\hline TEC & Skills, supply or technical constraints & FUD survey & 0 & 0 & 1 & 1 & 1 & 0,50 & 0,50 \\
\hline REG & Regulatory constraints & FUD survey & 0 & 0 & 0 & 1 & 1 & 0,31 & 0,46 \\
\hline$A G R$ & Branch or firm agreement & FUD survey & 0 & 0 & 0 & 0 & 1 & 0,16 & 0,37 \\
\hline BRA & Branch agreement & FUD survey & 0 & 0 & 0 & 0 & 1 & 0,12 & 0,33 \\
\hline FIR & Firm agreement & FUD survey & 0 & 0 & 0 & 0 & 1 & 0,13 & 0,33 \\
\hline OPP $\times$ REG & & FUD survey & 0 & 0 & 0 & 0 & 1 & 0,20 & 0,40 \\
\hline$O P P \times A G R$ & & FUD survey & 0 & 0 & 0 & 0 & 1 & 0,13 & 0,33 \\
\hline OPP $\times$ BRA & & FUD survey & 0 & 0 & 0 & 0 & 0 & 0,10 & 0,30 \\
\hline$O P P \times F I R$ & & FUD survey & 0 & 0 & 0 & 0 & 1 & 0,11 & 0,31 \\
\hline$R E G \times A G R$ & & FUD survey & 0 & 0 & 0 & 0 & 1 & 0,12 & 0,32 \\
\hline REG $\times$ BRA & & FUD survey & 0 & 0 & 0 & 0 & 1 & 0,10 & 0,30 \\
\hline$R E G \times F I R$ & & FUD survey & 0 & 0 & 0 & 0 & 0 & 0,09 & 0,28 \\
\hline$T F P$ & Total factor productivity in log & FiBEn & 2,43 & 2,62 & 2,84 & 3,10 & 3,38 & 2,87 & 0,40 \\
\hline$\Delta q$ & $1^{\text {st }}$ difference value added in log & FiBEn & $-0,17$ & $-0,06$ & 0,02 & 0,11 & 0,21 & 0,02 & 0,20 \\
\hline $\mathbf{w}$ & Labour cost per employee in log & FiBEn & 3,13 & 3,30 & 3,47 & 3,64 & 3,80 & 3,46 & 0,28 \\
\hline
\end{tabular}

\begin{tabular}{clc}
\hline $\begin{array}{c}\text { Industry } \\
\text { (control variables) }\end{array}$ & Frequency \\
\hline B0 & Agriculture and food industry (AFI) & 10.1 \\
C1 & Clothing, leather and footwear & 5.7 \\
C2 & Paper, printing and publishing & 7.0 \\
C3 & Chemical, rubber, plastics and fuel & 1.7 \\
C4 & Household equipment industries & 5.4 \\
D0 & Industry & 2.2 \\
E1 & Shipbuilding, aeronautic and railway industries & 1.5 \\
E2 & Mechanical equipment industries & 14.5 \\
E3 & Electric and electronic equipment industries & 3.4 \\
F1 & Mineral products industry & 3.8 \\
F2 & Textile industry & 3.7 \\
F3 & Wood and paper industry & 9.8 \\
F4 & Chemicals and plastics industry & 7.9 \\
F5 & Metallurgy and metal transformation & 20.0 \\
F6 & Electric and electronic components industry & 3.3 \\
\hline \hline
\end{tabular}

